\title{
LTB wt Allele
}

National Cancer Institute

\section{Source}

National Cancer Institute. LTB wt Allele. NCI Thesaurus. Code C51511.

Human LTB wild-type allele is located in the vicinity of $6 p 21.3$ and is approximately $5 \mathrm{~kb}$ in length. This allele, which encodes lymphotoxin-beta protein, plays a role in inflammatory responses and is involved in the normal development of lymphoid tissue. 